\title{
Plasma-Induced Catalyst Support Defects for the Photothermal Methanation of Carbon Dioxide
}

\author{
Salina Jantarang $(\mathbb{D}$, Simone Ligori, Jonathan Horlyck $\mathbb{D}$, Emma C. Lovell * $\mathbb{D}$, Tze Hao Tan, Bingqiao Xie (D), \\ Rose Amal and Jason Scott*
}

check for updates

Citation: Jantarang, S.; Ligori, S.; Horlyck, J.; Lovell, E.C.; Tan, T.H.; Xie B.; Amal, R.; Scott, J. Plasma-Induced Catalyst Support Defects for the Photothermal Methanation of Carbon Dioxide. Materials 2021, 14, 4195. https://doi.org/10.3390/ma14154195

Academic Editor: Kai Yan

Received: 4 June 2021

Accepted: 20 July 2021

Published: 28 July 2021

Publisher's Note: MDPI stays neutral with regard to jurisdictional claims in published maps and institutional affiliations.

Copyright: (c) 2021 by the authors. Licensee MDPI, Basel, Switzerland. This article is an open access article distributed under the terms and conditions of the Creative Commons Attribution (CC BY) license (https:// creativecommons.org/licenses/by/ $4.0 /)$.
Particles and Catalysis Research Group, School of Chemical Engineering, The University of New South Wales, Sydney, NSW 2052, Australia; salina.j@chula.ac.th (S.J.); simligori@gmail.com (S.L.); j.horlyck@outlook.com (J.H.); tze_hao.tan@unsw.edu.au (T.H.T.); bingqiao.xie@unsw.edu.au (B.X.); r.amal@unsw.edu.au (R.A.)

* Correspondence: e.lovell@unsw.edu.au (E.C.L.); jason.scott@unsw.edu.au (J.S.)

\begin{abstract}
The presence of defects in a catalyst support is known to benefit catalytic activity. In this work, a He-plasma treatment-based strategy for introducing and stabilising defects on a $\mathrm{Ni} / \mathrm{TiO}_{2}$ catalyst for photothermal $\mathrm{CO}_{2}$ hydrogenation was established. The impact of pretreatment step sequence-which comprised He-plasma treatment and reduction/passivation-on defect generation and stabilisation within the support was evaluated. Characterisation of the $\mathrm{Ni} / \mathrm{TiO}_{2}$ catalysts indicated that defects created in the $\mathrm{TiO}_{2}$ support during the initial plasma treatment stage were then stabilised by the reduction/passivation process, $(\mathrm{P}-\mathrm{R}) \mathrm{Ni} / \mathrm{TiO}_{2}$. Conversely, performing reduction/passivation first, ( $\mathrm{R}-\mathrm{P}) \mathrm{Ni} / \mathrm{TiO}_{2}$, invoked a resistance to subsequent defect formation upon plasma treatment and consequently, poorer photothermal catalytic activity. The plasma treatment altered the metal-support interaction and ease of catalyst reduction. Under photothermal conditions, $(\mathrm{P}-\mathrm{R}) \mathrm{Ni} / \mathrm{TiO}_{2}$ reached the highest methane production in $75 \mathrm{~min}$, while $(\mathrm{R}-\mathrm{P}) \mathrm{Ni} / \mathrm{TiO}_{2}$ required 165 min. Decoupling the impacts of light and heat indicated thermal dominance of the reaction with $\mathrm{CO}_{2}$ conversion observed from $200{ }^{\circ} \mathrm{C}$ onwards. Methane was the primary product with carbon monoxide detected at $350{ }^{\circ} \mathrm{C}(\sim 2 \%)$ and $400{ }^{\circ} \mathrm{C}(\sim 5 \%)$. Overall, the findings demonstrate the importance of pretreatment step sequence when utilising plasma treatment to generate active defect sites in a catalyst support.
\end{abstract}

Keywords: photothermal carbon dioxide methanation; plasma treatment; helium plasma; nickel catalyst; titania; defects

\section{Introduction}

The transformation of carbon dioxide $\left(\mathrm{CO}_{2}\right)$ to valuable hydrocarbon products is a promising approach to mitigate $\mathrm{CO}_{2}$ emissions to the atmosphere [1,2]. Amongst the fuels and chemicals which can be produced, methane is a desirable product as it can be used directly within our existing natural gas infrastructure $[3,4]$. One approach to driving the methanation reaction is through exploiting photothermal conditions, which relies on a temperature increase from light absorption by the catalyst. The photothermal conditions allow the reaction to occur without external heating and promote a sustainable approach for catalytic activity.

To date, studies surrounding photothermal $\mathrm{CO}_{2}$ methanation have focused on understanding the role of light and catalyst design, encompassing different active metals and catalysts [5-7]. Amongst the active metals studied for thermal $\mathrm{CO}_{2}$ hydrogenation, nickel (Ni) has been probed expansively due to its performance in $\mathrm{CO}_{2}$ hydrogenation and relative abundance [3,8-11]. With regard to catalyst supports, titania $\left(\mathrm{TiO}_{2}\right)$ has been studied comprehensively for thermal $\mathrm{CO}_{2}$ methanation $[9,12,13]$. $\mathrm{TiO}_{2}$, a semiconductor support, can harness light primarily in the ultraviolet (UV) region [14]. While catalysts have been prepared with varied metals and supports, the methods of catalyst modification, such as to induce defects, have not been reported extensively. The photothermal reaction is 
influenced by factors such as light harnessing, ease of catalyst reduction, and interaction with $\mathrm{CO}_{2}$ and $\mathrm{H}_{2}$ [15-17]. Therefore, pretreatments to alter catalyst structure can enhance the reaction.

One approach to modifying catalytic properties is by pretreating the catalyst [18-21]. Plasma treatment is capable of rapidly form defects without requiring additional chemicals or complex reactor set-ups. Non-thermal plasma pretreatment induce defects by bombarding the catalyst surface with excited species, typically easily ionised gases such as argon (Ar) or helium (He) [22,23]. This surface bombardment can result in a range of physical and chemical changes to the catalyst surface including etching, reducing the surface and altering metal deposit size and support interaction [22,23]. Plasma pretreatment has shown significant impacts on both metal oxide supports alone, as well as metal-supported catalysts. For example, Horlyck et al. examined the use of He plasma pretreatment on $\mathrm{TiO}_{2} / \mathrm{SiO}_{2}$ composites and found a significant increase in defect formation as a result of prolonged plasma treatment [24]. In the case of metal-supported catalysts, the effect of cold Ar plasma treatment on $\mathrm{Pt} / \mathrm{CeO}_{2}$ for the water-gas shift reaction has been studied. Compared to calcined $\mathrm{Pt} / \mathrm{CeO}_{2}$, the plasma treatment step altered the $\mathrm{Pt}$ species and resulted in an increase in electron density, stronger Pt-Ce interaction, and higher CO adsorption [25].

Plasma treatment, as a means of defecting catalysts and altering Ni properties, has not been investigated for pretreating catalysts used in the photothermal methanation of $\mathrm{CO}_{2}$. Overall, applying a plasma at different stages of catalyst preparation has been reported to impact material characteristics such as structural properties and metal-support interaction; subsequently influencing the catalytic performance.

In this work, plasma treatment was utilised to induce defects on $\mathrm{Ni} / \mathrm{TiO}_{2}$ catalysts for the photothermal conversion of $\mathrm{CO}_{2}$ to methane. $\mathrm{A} \mathrm{TiO}_{2}$ support was prepared by flame spray pyrolysis (FSP) and loaded with Ni. Plasma treatment was applied to either: (i) as-prepared $\mathrm{NiO} / \mathrm{TiO}_{2}$ prior to reduction/passivation; or (ii) after reduction/passivation of the as-prepared $\mathrm{NiO} / \mathrm{TiO}_{2}$. The plasma pretreatment can induce defects in the $\mathrm{TiO}_{2}$ support as well as influence the $\mathrm{Ni}$ catalyst properties. Its application at different points within the catalyst preparation process enables us to examine its influence on the $\mathrm{Ni} / \mathrm{TiO}_{2}$ catalyst characteristics and their subsequent catalyst activity. The $\mathrm{Ni} / \mathrm{TiO}_{2}$ catalysts were assessed for $\mathrm{CO}_{2}$ reduction under photothermal conditions in a batch-circulated reactor system, where light was the sole driving force for the reaction. To decouple the influence of light and heat on the catalytic process, the reaction was undertaken in a continuous flow reactor system. Within the continuous flow reactor, catalyst activity/selectivity under only either thermal stimulus or combined thermal-light stimuli, can be determined. The materials were characterised to gain an appreciation of the impact plasma treatment had on inducing defects in the $\mathrm{TiO}_{2}$ support and altering the Ni catalyst properties, and the ensuing catalytic activity for photothermal $\mathrm{CO}_{2}$ methanation.

\section{Materials and Methods}

\subsection{Catalyst Synthesis}

$\mathrm{TiO}_{2}$ was prepared by flame spray pyrolysis (FSP), with the synthesis conditions described elsewhere [26]. Briefly, titanium (IV) isopropoxide (97\%, Sigma-Aldrich, St. Louis, MO, USA) was mixed with absolute ethanol (Chem-Supply, Adelaide, Australia) to form a $1.26 \mathrm{M}$ precursor solution. The mixture was then fed into the flame via a syringe pump at a rate of $5 \mathrm{~mL} / \mathrm{min}$. A $5 \mathrm{~L} / \mathrm{min} \mathrm{O}_{2}$ sheath (oxygen, $>99.9 \%$, Coregas, Yennora, Australia) aided upward movement of the synthesised particles into the vacuum hood. The flame was supported with a mix of $1.5 \mathrm{~L} / \mathrm{min} \mathrm{CH}_{4}(>99.95 \%$, Coregas) and $3.2 \mathrm{~L} / \mathrm{min}$ $\mathrm{O}_{2}$. The precursor was dispersed using a $5 \mathrm{~L} / \mathrm{min}$ gas flow of $\mathrm{O}_{2}$, with the pressure drop across the nozzle maintained at $150 \mathrm{kPa}$. A vacuum pump connected to a Whatmann filter paper located above the flame was used to collect the product.

$\mathrm{NiO} / \mathrm{TiO}_{2}$ catalyst was prepared via impregnation and calcination. During the synthesis, nickel (II) nitrate hexahydrate (99.999\%, Sigma-Aldrich) was dissolved in Milli-Q water $(18.2 \mathrm{M} \Omega \cdot \mathrm{cm}$, Merck Millipore, Billerica, MA, USA) to form a $0.3 \mathrm{M}$ solution. The 
FSP-prepared $\mathrm{TiO}_{2}$ was added to the $\mathrm{Ni}$ solution and stirred at $120^{\circ} \mathrm{C}$ until a paste formed. The paste was further dried at $110^{\circ} \mathrm{C}$ in an oven for $16 \mathrm{~h}$ and then ground with a mortar and pestle. The powder was loaded into a glass reactor with a $10 \mathrm{~mm}$ internal diameter and calcined at $400{ }^{\circ} \mathrm{C}$ for $3 \mathrm{~h}$ under dry air (Coregas, $50 \mathrm{~mL} / \mathrm{min}$ ) at ramp rate of $5^{\circ} \mathrm{C} / \mathrm{min}$.

The $\mathrm{NiO} / \mathrm{TiO}_{2}$ catalysts were reduced and passivated in a Micromeritics Autochem 2910 (Micromeritics, Norcross, GA, USA). For the reduction step, $\sim 300 \mathrm{mg}$ of NiO catalyst was reduced in $10.18 \% \mathrm{H}_{2} / \mathrm{Ar}(20 \mathrm{~mL} / \mathrm{min})$ ramped to $500{ }^{\circ} \mathrm{C}$ at $5{ }^{\circ} \mathrm{C} / \mathrm{min}$, held for $1 \mathrm{~h}$, and then cooled under Ar. The reduced Ni catalyst was then passivated under $10 \mathrm{~mL} / \mathrm{min}$ $0.97 \% \mathrm{O}_{2} / \mathrm{He}$ (Coregas) for $12 \mathrm{~h}$ at room temperature, after which it was ground with a mortar and pestle.

Plasma treatment was undertaken using a Dielectric Barrier Discharge (DBD) plasma system (CTP-2000K Plasma Generator, Corona Lab, Nanjing, China), with a discharge gap of $\sim 8 \mathrm{~mm}$, as reported elsewhere [24]. Typically, $\sim 250 \mathrm{mg}$ of catalyst was loaded into the plasma chamber and subjected to plasma under a $30 \mathrm{~mL} / \mathrm{min} \mathrm{He}(>99.996 \%$, Coregas) flow for 20 min. Plasma treatment was conducted on either: (i) the as-prepared $\mathrm{NiO} / \mathrm{TiO}_{2}$ prior to reduction and passivation; or (ii) samples that had been initially reduced and passivated. The catalysts are labelled based on the pretreatment order where reduced/passivated and then plasma treated is $(\mathrm{R}-\mathrm{P}) \mathrm{Ni} / \mathrm{TiO}_{2}$, plasma treated and then reduced/passivated is $(\mathrm{P}-\mathrm{R}) \mathrm{Ni} / \mathrm{TiO}_{2}$. A catalyst that has been only reduced/passivated (i.e., no plasma treatment) is referred to as $(\mathrm{R}) \mathrm{Ni} / \mathrm{TiO}_{2}$. A catalyst that has been only plasma-treated (i.e., no reduction/passivation) is referred to as $(\mathrm{P}) \mathrm{NiO} / \mathrm{TiO}_{2}$.

\subsection{Catalyst Characterisation}

To determine the actual $\mathrm{Ni}$ loading on the catalyst, the as-prepared $\mathrm{NiO} / \mathrm{TiO}_{2}$ was digested in aqua regia using microwave assistance and subject to inductively coupled plasma optical emission spectrometry (ICP-OES) using a PerkinElmer OPTIMA 7300 ICP-OES instrument (PerkinElmer, Waltham, MA, USA).

Specific surface area (SSA) was measured using $\mathrm{N}_{2}$ adsorption/desorption isotherms (Micromeritics Tristar 3030) at $-196^{\circ} \mathrm{C}$. The samples were pretreated under vacuum for $3 \mathrm{~h}$ at $150{ }^{\circ} \mathrm{C}$ prior to analysis. The SSA was determined by the Brunauer-Emmet-Teller (BET) method. Material phases and crystallinity were analysed using X-ray diffraction (XRD) with a PANalytical Xpert Multipurpose X-ray Diffraction System (MPD) (Malvern, $\mathrm{UK})$. The XRD instrument was set at $45 \mathrm{kV}$ and $40 \mathrm{~mA}$ with a $\mathrm{Cu} \mathrm{K} \alpha$ source. The pattern was collected over the range of $2 \theta=20^{\circ}-100^{\circ}$ with a scan rate of $0.01^{\circ} / \mathrm{min}$ and a step size of $0.026^{\circ}$. The Scherrer equation was used to calculate the crystal size using the $100 \%$ intensity peak and a shape factor of 0.9 .

As light absorbance by the Ni catalysts is critical for driving the photothermal methanation reaction, the materials were characterised by ultraviolet-visible-near infrared (UVvis-NIR) spectrometry using a Shimadzu UV-Vis 3600 (Shimadzu, Kyoto, Japan). The collected reflectance spectra were converted to absorbance spectra via the Kubelka-Munk equation, referenced to barium sulphate. Subsequently, the converted spectra of nickelloaded samples were normalised against absorbance of $\mathrm{TiO}_{2}$.

Catalyst reducibility was characterised using a Micromeritics Autochem 2910 (Micromeritics, Norcross, GA, USA). For the hydrogen-temperature programmed reduction $\left(\mathrm{H}_{2}-\mathrm{TPR}\right)$ procedure, approximately $50 \mathrm{mg}$ of catalyst was loaded into a quartz U-tube, supported by a plug of quartz wool. The catalyst was pretreated under an argon $(>99.997 \%$, Coregas) flow $(20 \mathrm{~mL} / \mathrm{min})$ where it was heated to $150{ }^{\circ} \mathrm{C}$ at a rate of $10{ }^{\circ} \mathrm{C} / \mathrm{min}$ and held for $0.5 \mathrm{~h}$. The sample was then cooled to $50{ }^{\circ} \mathrm{C}$ prior to introducing $10.18 \% \mathrm{H}_{2} / \mathrm{Ar}$ (Coregas) at $20 \mathrm{~mL} / \mathrm{min}$. Heating from $50{ }^{\circ} \mathrm{C}$ to $700{ }^{\circ} \mathrm{C}$ at a ramp rate of $5{ }^{\circ} \mathrm{C} / \mathrm{min}$ was applied and the $\mathrm{H}_{2}$ consumed was measured by a TCD. $\mathrm{CO}_{2}$-temperature programmed desorption ( $\left.\mathrm{CO}_{2}-\mathrm{TPD}\right)$ experiments were also conducted on the Micromeritics Autochem 2910. Here, approximately $50 \mathrm{mg}$ of sample was placed into the quartz U-tube. The catalyst was initially reduced in $10.18 \% \mathrm{H}_{2} / \mathrm{Ar}(20 \mathrm{~mL} / \mathrm{min})$ ramped at $5{ }^{\circ} \mathrm{C} / \mathrm{min}$ up to $500{ }^{\circ} \mathrm{C}$, held for $1 \mathrm{~h}$, and cooled to $50{ }^{\circ} \mathrm{C}$ in $20 \mathrm{~mL} / \mathrm{min}$ He. The sample was next exposed to $20 \mathrm{~mL} / \mathrm{min}$ 
$\mathrm{CO}_{2}\left(>99.5 \%\right.$, Coregas) for $1 \mathrm{~h}$ at $50^{\circ} \mathrm{C}$ after the gas flow was swapped to $\mathrm{He}$ for $1 \mathrm{~h}$. The $\mathrm{CO}_{2}-\mathrm{TPD}$ was conducted in $20 \mathrm{~mL} / \mathrm{min} \mathrm{He}$ from $50^{\circ} \mathrm{C}$ to $700^{\circ} \mathrm{C}$ at a ramp rate $10^{\circ} \mathrm{C} / \mathrm{min}$. Surface species present on the pretreated $\mathrm{Ni} / \mathrm{TiO}_{2}$ catalysts were identified by $\mathrm{X}$ ray photoelectron spectroscopy (XPS). Shifts in binding in energy were referenced to the Carbon 1s peak (284.8 eV) and the spectra were collected using an ESCALAB 250Xi (Thermo Scientific, Waltham, MA, USA) equipped with an Al K $\alpha$ X-ray source. Transmission electron microscopy (TEM) images and energy-dispersive spectroscopy (EDS) mapping were taken by a JEOL JEM-ARM200F microscope (JEOL Ltd., Tokyo, Japan), operating at $200 \mathrm{kV}$. Prior to the imaging, the $\mathrm{Ni} / \mathrm{TiO}_{2}$ catalysts were ultrasonically dispersed in ethanol and dropcast onto lacy carbon-coated copper grids. Defects present in the $\mathrm{TiO}_{2}$ were evaluated using electron paramagnetic resonance (EPR) and Raman spectroscopies. EPR was conducted at $-153^{\circ} \mathrm{C}$ (cooled by liquid nitrogen) using $20 \mathrm{mg}$ of sample loaded in a $4 \mathrm{~mm}$ (internal diameter) quartz tube and analysed by a Bruker EMX X-Band ESR spectrometer (Bruker, Billerica, MA, USA). Raman spectroscopy was performed using a Renishaw inVia 2 Raman Microscope (532 nm) (Renishaw, Wotton-under-Edge, UK).

\subsection{Activity Tests}

Two styles of activity testing were conducted to gain an understanding of the impacts of plasma treatment on catalyst performance for the photothermal methanation of $\mathrm{CO}_{2}$ : (i) the first utilised a batch-circulated reactor system; (ii) the second employed a continuous flow reactor system where the effects of light and heat on catalyst performance could be decoupled. Details on the two reactor configurations and associated catalyst activity/selectivity evaluation are available in an earlier study [16].

In the case of the batch-circulated reactor system, illumination was provided from the top of the reactor using a $300 \mathrm{~W}$ Xenon lamp (Peccell CX-04E with an Eagle R300-3J lamp housing) (Peccell Technologies, Yokohama, Japan). No other heat source was employed. The catalyst was supported on a glass fibre filter (Merck Millipore, Billerica, MA, USA) within the reactor. To load the catalyst, $100 \mathrm{mg}$ of sample was ultrasonically dispersed in Milli-Q water and drop-cast on to a $7 \mathrm{~cm}^{2}$ region of the filter, dried and then placed in the reactor. A reactant mixture comprising $\sim 15 \mathrm{kPa} \mathrm{CO}$ and $\sim 60 \mathrm{kPa}$ hydrogen $\left(\mathrm{H}_{2},>99.99 \%\right.$, Coregas) was injected into, and continuously circulated around, the reactor. The reactor was illuminated using the Xenon lamp (20 A current output) to initiate the photothermal methanation reaction. Reactants and products were analysed using a gas chromatograph (Shimadzu GC-2010 Plus with a Supelco Carboxen 1010 column) (Shimadzu, Kyoto, Japan). The gas chromatograph was equipped with a methaniser, flame ionisation detector (FID) and TCD. The change in temperature of the catalyst was monitored using a thermocouple in direct contact with the catalyst-loaded filter.

In the case of the continuous flow reactor system, heat was supplied from beneath the reactor using a tube furnace. The catalyst was illuminated by a Xenon lamp ( $300 \mathrm{~W}$, 20 A current output) through a quartz window in the top of the reactor. The catalyst $(100 \mathrm{mg})$ was loaded on an $(1.5 \mathrm{~cm} \times 1.5 \mathrm{~cm})$ aluminium plate and placed in the reactor facing upwards. Under thermal-only reaction conditions, the temperature increased from $50-400{ }^{\circ} \mathrm{C}$, at $50{ }^{\circ} \mathrm{C}$ intervals, under a $4 \mathrm{~mL} / \mathrm{min} \mathrm{CO}_{2}$ and $16 \mathrm{~mL} / \mathrm{min}_{2}$ reactant flow. The temperature was ramped at $2.5^{\circ} \mathrm{C} / \mathrm{min}$ and held for $1 \mathrm{~h}$ at each temperature interval. The impact of light was studied by replicating the thermal reaction conditions with the addition of catalyst illumination from above. Reactants and products from the reactor effluent were identified using a Shimadzu GC-2010 gas chromatograph (Shimadzu, Kyoto, Japan) equipped with an Agilent J\&W HP-PLOT Q capillary column, methaniser and FID. A schematic of the apparatus can be found in Tan et al. [27].

\section{Results and Discussion}

\subsection{Catalyst Properties}

The structural properties of $\mathrm{Ni} / \mathrm{TiO}_{2}$ are displayed in Table 1. As determined from ICP-OES, the actual Ni loading was $9.2 \mathrm{wt} . \%$, close to the nominal $10 \mathrm{wt} . \%$ loading. The 
as-prepared $\mathrm{FSP} \mathrm{TiO}_{2}$ had a SSA of $104 \mathrm{~m}^{2} / \mathrm{g}$. The type $\mathrm{III} \mathrm{N}_{2}$ adsorption/desorption isotherms of $\mathrm{TiO}_{2}$ (Figure S2) indicates a non-porous structure. The pore size distribution (Figure S2) shows a maximum at approximately $3.46 \mathrm{~nm}$ for $\mathrm{TiO}_{2}$. After loading the $\mathrm{TiO}_{2}$ with $\mathrm{Ni}$ and subsequent calcination $\left(\mathrm{NiO} / \mathrm{TiO}_{2}\right)$, the SSA decreased to $66 \mathrm{~m}^{2} / \mathrm{g}$. Plasmatreating the $\mathrm{NiO} / \mathrm{TiO}_{2}\left((\mathrm{P}) \mathrm{NiO} / \mathrm{TiO}_{2}\right)$ saw the SSA increase slightly to $75 \mathrm{~m}^{2} / \mathrm{g}$. Both $\mathrm{NiO} / \mathrm{TiO}_{2}$ and $(\mathrm{P}) \mathrm{NiO} / \mathrm{TiO}_{2}$ displayed type $\mathrm{V}$ isotherms. Two peaks, centred at $4.2-5.1 \mathrm{~nm}$ and $8.7-9.1 \mathrm{~nm}$, were observed in the pore size distribution of the nickel catalysts. As the catalysts are non-porous, the porosity observed from $\mathrm{N}_{2}$ adsorption/desorption isotherm is likely to stem from spaces between the particles. The catalyst structure and metal distribution are discussed at the end of this section.

Table 1. BET specific surface area and crystallite size $\left(\mathrm{TiO}_{2}, \mathrm{NiO}\right.$, and $\left.\mathrm{Ni}\right)$ of as-prepared and pretreated $\mathrm{Ni} / \mathrm{TiO}$.

\begin{tabular}{|c|c|c|c|c|c|}
\hline Catalyst & Pretreatment $^{a}$ & $S_{\text {BET }}\left(\mathrm{m}^{2} / \mathrm{g}\right)^{b}$ & $\begin{array}{c}\mathrm{TiO}_{2} \\
\text { (nm) }^{\mathrm{c}} \\
\end{array}$ & $\begin{array}{c}\text { NiO Crystal Size } \\
(\mathrm{nm})^{\mathrm{c}}\end{array}$ & $\begin{array}{c}\text { Ni Crystal Size } \\
(\text { nm) })^{c}\end{array}$ \\
\hline $\mathrm{TiO}_{2}$ & $\mathrm{~N} / \mathrm{A}$ & 104 & 22.0 & $\mathrm{~N} / \mathrm{A}$ & $\mathrm{N} / \mathrm{A}$ \\
\hline $\mathrm{NiO} / \mathrm{TiO}_{2}$ & $\mathrm{~N} / \mathrm{A}$ & 66 & 21.0 & 7.7 & $\mathrm{~N} / \mathrm{A}$ \\
\hline$(\mathrm{R}) \mathrm{Ni} / \mathrm{TiO}_{2}$ & Reduced & N.D. & 23.6 & $\mathrm{~N} / \mathrm{A}$ & 13.1 \\
\hline$(\mathrm{P}) \mathrm{NiO} / \mathrm{TiO}_{2}$ & Plasma treated & 75 & 21.0 & 9.3 & $\mathrm{~N} / \mathrm{A}$ \\
\hline$(\mathrm{P}-\mathrm{R}) \mathrm{Ni} / \mathrm{TiO}_{2}$ & $\begin{array}{l}\text { Plasma treated } \\
\text { then reduced }\end{array}$ & N.D. & 22.6 & $\mathrm{~N} / \mathrm{A}$ & 13.7 \\
\hline$(\mathrm{R}-\mathrm{P}) \mathrm{Ni} / \mathrm{TiO}_{2}$ & $\begin{array}{l}\text { Reduced then } \\
\text { plasma treated }\end{array}$ & N.D. & 23.0 & $\mathrm{~N} / \mathrm{A}$ & 12.7 \\
\hline
\end{tabular}

a "Reduced" refers to "reduction/passivation". ${ }^{\mathrm{b}}$ BET specific surface area. ${ }^{\mathrm{c}}$ Calculated from $100 \%$ intensity peak of XRD pattern (Figure S2).

The crystal phase and size of the $\mathrm{TiO}_{2}$ support and $\mathrm{Ni}$ deposits were determined from the XRD patterns (Figure S2). Both anatase and rutile $\mathrm{TiO}_{2}$ were detected; however, the anatase phase was dominant, which is consistent with $\mathrm{TiO}_{2}$ synthesised by FSP [26]. The $\mathrm{TiO}_{2}$ crystal phase was not affected by plasma treatment or Ni addition and calcination. Plasma treatment had a minimal impact on the $\mathrm{NiO}$ crystallite size $\left(\mathrm{NiO} / \mathrm{TiO}_{2}: 7.7 \mathrm{~nm}\right.$, $\left.(\mathrm{P}) \mathrm{NiO} / \mathrm{TiO}_{2}: 9.3 \mathrm{~nm}\right)$ and the $\mathrm{TiO}_{2}$ crystal size $(21 \mathrm{~nm})$ remained unchanged. Upon reduction/passivation, the $\mathrm{Ni}$ crystal sizes were similar $\left((\mathrm{P}-\mathrm{R}) \mathrm{Ni} / \mathrm{TiO}_{2}: 13.7 \mathrm{~nm},(\mathrm{R}) \mathrm{Ni} / \mathrm{TiO}_{2}\right.$ : $\left.13.1 \mathrm{~nm},(\mathrm{R}-\mathrm{P}) \mathrm{Ni} / \mathrm{TiO}_{2}: 12.7 \mathrm{~nm}\right)$, indicating that the plasma treatment had little impact on this characteristic. The BET and XRD results indicate the plasma pretreatment does not impart any undesirable morphological changes.

As plasma treatment has the potential to induce defects on the $\mathrm{TiO}_{2}$ support, the asprepared, plasma-treated and reduced/passivated $\mathrm{TiO}_{2}$ (without Ni loading) were studied by EPR and Raman spectroscopy (Figure 1). The EPR spectrum exhibits a peak at $g=2.0020$ for the as-prepared $\mathrm{TiO}_{2}$, associated with the presence of oxygen vacancies [28,29]. The peak representing $\mathrm{Ti}^{3+}(\mathrm{g} \approx 1.94)$ was not observed [28]. The EPR spectrum remains unchanged after plasma treating the $\mathrm{TiO}_{2}\left((\mathrm{P}) \mathrm{TiO}_{2}\right)$, with no shift in the $\mathrm{g}=2.0020$ peak position and no new peaks appearing. Similarly, the EPR spectrum for the passivated/reduced sample (Figure S3a) remains unchanged.

Raman spectroscopy was used to further understand the influence of plasma treatment on the $\mathrm{TiO}_{2}$ (Figure $1 \mathrm{~b}, \mathrm{c}$ ). Peaks corresponding to the anatase phase of $\mathrm{TiO}_{2}$ were evident for both samples $\left(143 / 144 \mathrm{~cm}^{-1}, 396 / 397 \mathrm{~cm}^{-1}, 516 \mathrm{~cm}^{-1}\right.$, and $\left.638 / 639 \mathrm{~cm}^{-1}\right)[30,31]$. This is consistent with the presence of anatase from XRD (Figure S2). The peak at $143 / 144 \mathrm{~cm}^{-1}$ is the linear combination of asymmetric bending of O-Ti-O bonds, while $197 / 198 \mathrm{~cm}^{-1}$ can be attributed to the presence of the brookite phase [30]. Consistent with the XRD results, no significant peak shifts or broadening was evident as a consequence of the plasma treatment, indicating no major structural changes. A peak at $1050 \mathrm{~cm}^{-1}$ appeared for $(\mathrm{P}) \mathrm{TiO}_{2}$, which is not commonly observed in $\mathrm{TiO}_{2}$. Surmacki et al. [32] observed a peak at $1048 \mathrm{~cm}^{-1}$ in an electron beam irradiated $\mathrm{N}$-doped $\mathrm{TiO}_{2}$ sample which was not observed in the nonirradiated sample. They attributed it to a new species from the interaction of the $\mathrm{TiO}_{2}$ and $\mathrm{N}$-dopant under irradiation, although it was not assigned to a specific feature of $\mathrm{TiO}_{2}$. 
Plasma treatment of $\mathrm{FSP} \mathrm{SiO}_{2}-\mathrm{TiO}_{2}$ saw the emergence of a new Raman peak at $440 \mathrm{~cm}^{-1}$ for that sample, which was attributed to structural distortion [24]. Although the peak at $1050 \mathrm{~cm}^{-1}$ (Figure 1c) has not been defined in the literature, the formation the additional peak for $(\mathrm{P}) \mathrm{TiO}_{2}$ indicates that a structural change occurred due to the plasma treatment. A similar change in the Raman spectra of $(\mathrm{R}) \mathrm{TiO}_{2},(\mathrm{P}-\mathrm{R}) \mathrm{TiO}_{2}$, and $(\mathrm{R}-\mathrm{P}) \mathrm{TiO}_{2}$ was not apparent, suggesting that the reduction/passivation may constrain the effect of plasma on the $\mathrm{TiO}_{2}$.
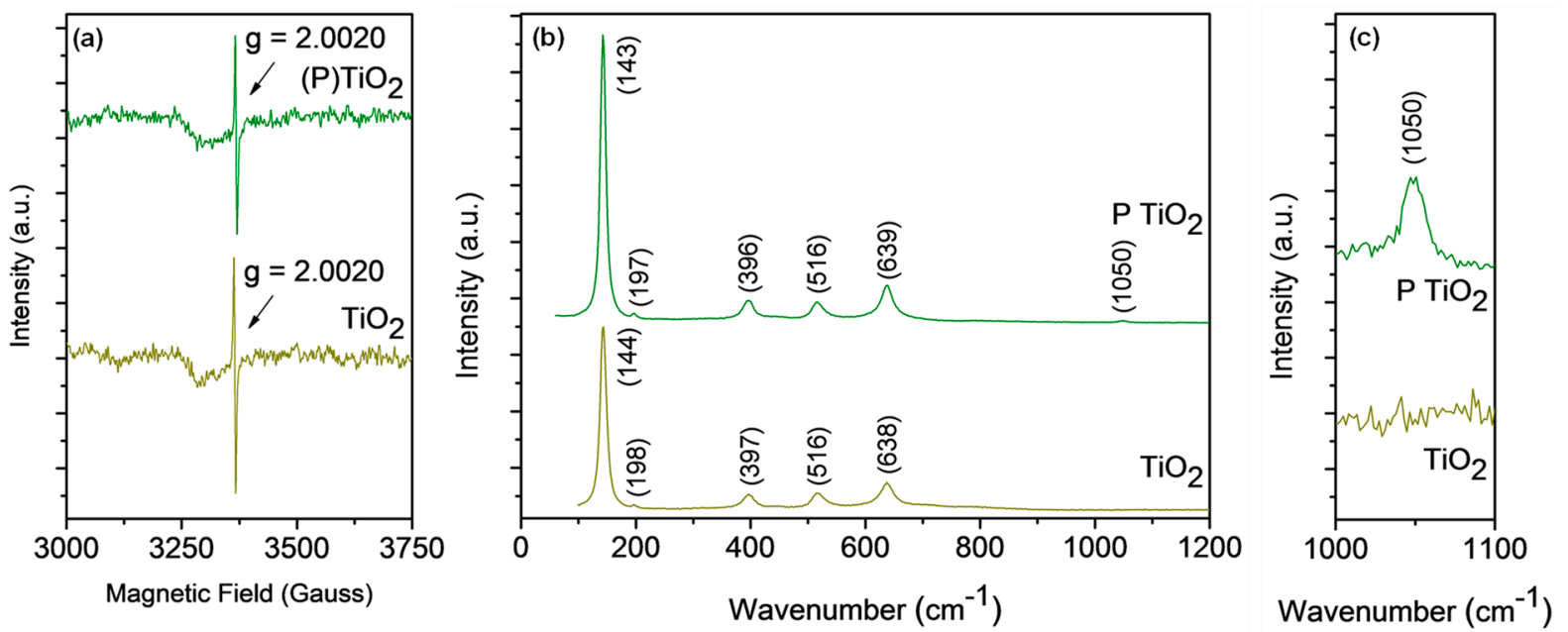

Figure 1. (a) EPR spectra of $\mathrm{TiO}_{2}$ and plasma-treated $\mathrm{TiO}_{2}\left((\mathrm{P}) \mathrm{TiO}_{2}\right) ; \operatorname{Raman}$ spectra of $\mathrm{TiO}_{2}$ and $(\mathrm{P}) \mathrm{TiO}_{2}(\mathbf{b}) 0-1200 \mathrm{~cm}^{-1}$ and (c) magnified spectra at $1000-1100 \mathrm{~cm}^{-1} . \mathrm{P}=$ plasma treated.

As the photothermal $\mathrm{CO}_{2}$ hydrogenation reaction utilises light to heat conversion, the light absorbance of $\mathrm{Ni} / \mathrm{TiO}_{2}$ was studied by UV-vis-NIR spectroscopy (Figure 2a). The as-prepared $\mathrm{TiO}_{2}$ absorbed light in the UV region and exhibited a bandgap of $3.4 \mathrm{eV}$. The calculated bandgap was consistent with the literature, particularly for anatase $\mathrm{TiO}_{2}$ at $\sim 3.2 \mathrm{eV}$. [33,34], which was the dominant phase present in the materials. Upon Ni addition and pretreatment, the light absorbance extends from the UV region into the visible and near infrared. The absorbance in the Vis and NIR regions can be attributed to the presence of metallic Ni deposits, consistent with group VIII metals [35]. Specifically, the broadband absorbance is driven by intraband transition within overlaid partially filled $3 \mathrm{~d}$ sub-orbitals [36]. All $\mathrm{Ni} / \mathrm{TiO}_{2}$ catalysts exhibited full spectrum absorbance, coinciding with the spectrum profile of the Xenon lamp, which allows utilisation of the full solar spectrum for the photothermal $\mathrm{CO}_{2}$ reaction.

To understand the impact of plasma treatment on the support, $\mathrm{CO}_{2}-\mathrm{TPD}$ analyses were conducted on the neat $\mathrm{TiO}_{2}$ (Figure 2b). $\mathrm{A} \mathrm{CO}_{2}$ desorption peak was centred at $190{ }^{\circ} \mathrm{C}$ and $194{ }^{\circ} \mathrm{C}$ for $\mathrm{TiO}_{2}$ and $(\mathrm{P}) \mathrm{TiO}_{2}$, respectively, which indicates medium-strength basic sites [37]. The desorption temperature is favourable, as it is within the temperature range of photothermal $\mathrm{CO}_{2}$ methanation. Relative to $\mathrm{TiO}_{2}$, the area under the peak for $(\mathrm{P}) \mathrm{TiO}_{2}$ increased by $11 \%$, indicating a mild increase in $\mathrm{CO}_{2}$ adsorption and the effectiveness of plasma treatment in inducing defects in $\mathrm{TiO}_{2}$. Defects present on $\mathrm{TiO}_{2}$ can behave as sites for $\mathrm{CO}_{2}$ adsorption [38]. Subsequently, the increase in $\mathrm{CO}_{2}$ desorption peak area can be a contributing factor to the improved activity.

The reducibility of $\mathrm{NiO} / \mathrm{TiO}_{2}$ and pretreated $\mathrm{Ni} / \mathrm{TiO}_{2}$ catalysts was characterised by $\mathrm{H}_{2}$-TPR (Figure 2c,d). As shown in Figure 2c, the as-prepared $\mathrm{TiO}_{2}$ has a low intensity peak between $200-250{ }^{\circ} \mathrm{C}$, which may arise from the partial reduction in $\mathrm{TiO}_{2}$ [39] or the removal of residual surface species resulting from the flame synthesis. For $\mathrm{NiO} / \mathrm{TiO}_{2}$, peaks are observed at $\sim 205^{\circ} \mathrm{C}, 335^{\circ} \mathrm{C}$, and $425^{\circ} \mathrm{C}$. The ratio of integrated $\mathrm{H}_{2}$-TPR peak area was $0.97: 1$ for $(\mathrm{P}) \mathrm{NiO} / \mathrm{TiO}_{2}: \mathrm{NiO} / \mathrm{TiO}_{2}$, which indicated that slightly less $\mathrm{H}_{2}$ was required to reduce $(\mathrm{P}) \mathrm{NiO} / \mathrm{TiO}_{2}$. The lower temperature reduction peaks for $\mathrm{NiO} / \mathrm{TiO}_{2}$ can be attributed to the reduction in $\mathrm{NiO}$ that weakly interacts with $\mathrm{TiO}_{2}$. The reduction in nickel 
oxide occurs at $\sim 400{ }^{\circ} \mathrm{C}$ [40]. The broad peak extending up to $\sim 500{ }^{\circ} \mathrm{C}$ can be attributed to $\mathrm{NiO}$ with a strong $\mathrm{NiO}-\mathrm{TiO}_{2}$ interaction [41]. After plasma treatment, $(\mathrm{P}) \mathrm{NiO} / \mathrm{TiO}_{2}$ (Figure 2c) displayed a slight decrease in reduction temperature of all peaks to $\sim 195^{\circ} \mathrm{C}$, $310^{\circ} \mathrm{C}$, and $400{ }^{\circ} \mathrm{C}$, implying an ease in reducibility and a slight variation to the metalsupport interaction. An increase in the ratio of the lowest temperature peak $\left(\sim 200^{\circ} \mathrm{C}\right)$ to the higher reduction peak $\left(\sim 250^{\circ} \mathrm{C}\right.$ to $\left.\sim 500^{\circ} \mathrm{C}\right)$ was observed for $(\mathrm{P}) \mathrm{NiO} / \mathrm{TiO}_{2}$. The peak at $\sim 205^{\circ} \mathrm{C}$ for $\mathrm{NiO} / \mathrm{TiO}_{2}$ accounted for $27 \%$ of its reduction profile, while the peak at $\sim 195{ }^{\circ} \mathrm{C}$ for $(\mathrm{P}) \mathrm{NiO} / \mathrm{TiO}_{2}$ accounted for $32 \%$ of its reduction profile. The $5 \%$ increase in the low temperature peak in $(\mathrm{P}) \mathrm{NiO} / \mathrm{TiO}_{2}$ relative to $\mathrm{NiO} / \mathrm{TiO}_{2}$ depicts an increase in $\mathrm{NiO}$ with weak metal-support interaction due to plasma treatment.
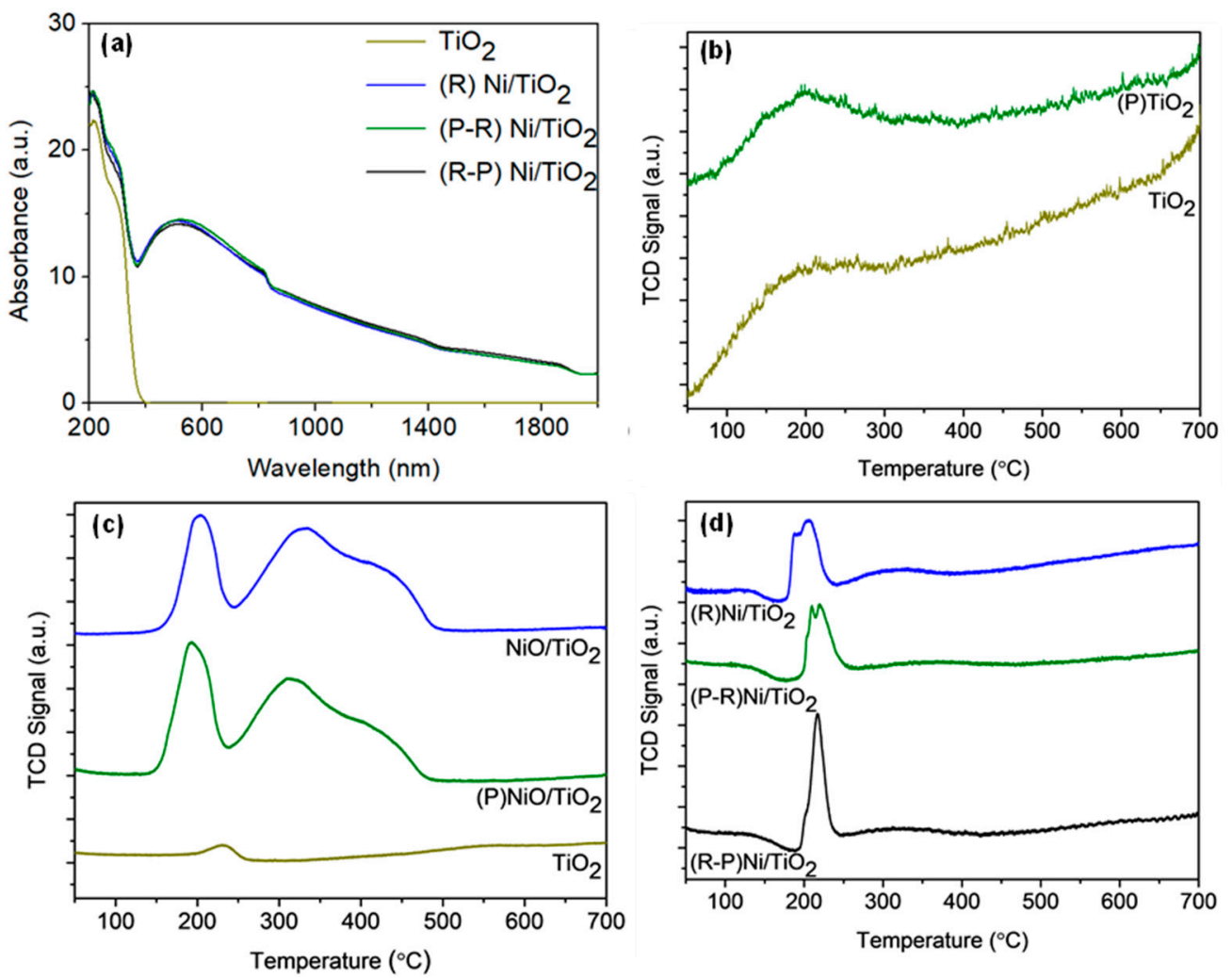

Figure 2. (a) UV-vis-NIR absorbance of $\mathrm{TiO}_{2}$ and pretreated $\mathrm{Ni} / \mathrm{TiO}_{2} ;$ (b) $\mathrm{CO}_{2}-\mathrm{TPD}$ of $\mathrm{TiO}_{2}$ and plasma-treated $\mathrm{TiO} 2$ $\left((\mathrm{P}) \mathrm{TiO}_{2}\right) ; \mathrm{H}_{2}-\mathrm{TPR}$ of $(\mathbf{c}) \mathrm{TiO}_{2}$ and $\mathrm{NiO} / \mathrm{TiO}_{2}$ and $(\mathbf{d})$ pretreated $\mathrm{Ni} / \mathrm{TiO}_{2} . \mathrm{R}=$ reduced/passivated, $\mathrm{P}=$ plasma treated.

Following reduction/passivation, the $\mathrm{Ni} / \mathrm{TiO}_{2}$ was reducible at temperatures below $250{ }^{\circ} \mathrm{C}$ (Figure $2 \mathrm{~d}$ ). The oxygen passivation was conducted to prevent uncontrolled oxidation after catalyst reduction. The decrease in the reduction temperature post-passivation, relative to as-prepared $\mathrm{NiO} / \mathrm{TiO}_{2}$, is important, as the onset temperature reached in the photothermal system is approximately $200{ }^{\circ} \mathrm{C}$ [16]. The post-passivation reduction peaks for (R)Ni/ $\mathrm{TiO}_{2}$ and $(\mathrm{P}-\mathrm{R}) \mathrm{Ni} / \mathrm{TiO}_{2}$ can be deconvoluted into two peaks $\left((\mathrm{R}) \mathrm{Ni} / \mathrm{TiO}_{2}: \sim 190{ }^{\circ} \mathrm{C}\right.$ and $205^{\circ} \mathrm{C},(\mathrm{P}-\mathrm{R}) \mathrm{Ni} / \mathrm{TiO}_{2}$ : $\sim 210{ }^{\circ} \mathrm{C}$ and $220{ }^{\circ} \mathrm{C}$. The post-passivation reduction profile for $(\mathrm{R}-\mathrm{P}) \mathrm{Ni} / \mathrm{TiO}_{2}$ was different, with only one reduction peak present at $\sim 215^{\circ} \mathrm{C}$ and a shoulder at $200^{\circ} \mathrm{C}$. These peaks are indicative of the re-reduction in the surface oxidised $\mathrm{Ni}$ deposits after passivation. The peak ratio, integrated from $\sim 180{ }^{\circ} \mathrm{C}$ to $\sim 270{ }^{\circ} \mathrm{C}$ and normalised to (R)Ni/ $\mathrm{TiO}_{2}$, was (R-P)Ni/ $\mathrm{TiO}_{2}(1.01)>(\mathrm{R}) \mathrm{Ni} / \mathrm{TiO}_{2}(1)>(\mathrm{P}-\mathrm{R}) \mathrm{Ni} / \mathrm{TiO}_{2}(0.83)$. The extent of re-oxidation from the oxygen passivation was calculated: (R-P)Ni/ $\mathrm{TiO}_{2}$ $(7.5 \%) \approx(\mathrm{R}) \mathrm{Ni} / \mathrm{TiO}_{2}(7.4 \%)>(\mathrm{P}-\mathrm{R}) \mathrm{Ni} / \mathrm{TiO}_{2}(6.3 \%)$. Whilst the percent oxidation was comparable between the catalysts, a clear difference in profile features is evident for the (R-P)Ni/ $\mathrm{TiO}_{2}$ compared to $(\mathrm{R}) \mathrm{Ni} / \mathrm{TiO}_{2}$ and $(\mathrm{P}-\mathrm{R}) \mathrm{Ni} / \mathrm{TiO}_{2}$, where two reduction peaks are present, whilst in the case of the $(\mathrm{R}-\mathrm{P}) \mathrm{Ni} / \mathrm{TiO}_{2}$ sample, a peak with a lower temperature 
shoulder is evident. This may be an impact of the re-reduction in different Ni sizes (vide infra). The change in reduction profile for (R-P)Ni/ $\mathrm{TiO}_{2}$ compared to (R)Ni/ $\mathrm{TiO}_{2}$ and $(\mathrm{P}-\mathrm{R}) \mathrm{Ni} / \mathrm{TiO}_{2}$ indicates that the plasma treatment had the most significant impact on the $\mathrm{Ni}$ deposits when implemented after reduction and passivation. However, (P-R)Ni/ $\mathrm{TiO}_{2}$ required the least $\mathrm{H}_{2}$ for re-reduction and subsequently ease of catalyst activation.

XPS was conducted on the $\mathrm{Ni} / \mathrm{TiO}_{2}$ to examine their surface oxidation state (Figure 3). Peaks corresponding to $\mathrm{Ni}^{2+}$ (nickel oxide) and $\mathrm{Ni}^{0}$ (metallic nickel) were identified as seen in Figure 3a, while the unlabelled peaks (at $861.4 \mathrm{eV}$ and $856.6 \mathrm{eV}$ ) are satellite peaks [42]. The ratio of $\mathrm{Ni}^{2+}$ to $\mathrm{Ni}^{0}$ was calculated to be (R-P)Ni/ $\mathrm{TiO}_{2}(6.0)>(\mathrm{R}) \mathrm{Ni} / \mathrm{TiO}_{2}(4.6)>(\mathrm{P}-$ $\mathrm{R}) \mathrm{Ni} / \mathrm{TiO}_{2}$ (4.3). The ratio was consistent with the $\mathrm{H}_{2}$ - TPR results for $\mathrm{Ni} / \mathrm{TiO}_{2}$ (Figure 2d) for which (P-R)Ni/ $\mathrm{TiO}_{2}$ had the lowest quantity of NiO. As is evident in Figure 3b, only a peak corresponding to $\mathrm{Ti}^{4+}$ was present in all samples. A shift in the binding energy of $\mathrm{Ti}^{4+}$ was observed as a consequence of the impact of plasma, indicating the presence of oxygen vacancy $\left(\mathrm{Ti}^{3+}\right)$ formation [43]. The shift in the $\mathrm{Ti}^{4+}$ peak for (P-R)Ni/ $\mathrm{TiO}_{2}$ (from $458.6 \mathrm{eV}$ to $458.4 \mathrm{eV}$ ) and (R-P)Ni/ $\mathrm{TiO}_{2}$ (from $458.6 \mathrm{eV}$ to $458.4 \mathrm{eV}$ ), compared to (R) Ni/ $/ \mathrm{TiO}_{2}$ indicates a change in Ti oxidation state arising from plasma treatment. The $\mathrm{O}$ 1s spectrum of (R)Ni/ $\mathrm{TiO}_{2}$ can be deconvoluted to lattice oxygen $(529.7 \mathrm{eV}),-\mathrm{OH}$ bond $(531.2 \mathrm{eV})$, and adsorbed water $(532.7 \mathrm{eV})[44,45]$. Corresponding shifts of the oxygen lattice from plasma treatment were observed in (P-R)Ni/ $\mathrm{TiO}_{2}$ and (R-P)Ni/ $\mathrm{TiO}_{2}$, from $529.7 \mathrm{eV}$ in $(\mathrm{R}) \mathrm{Ni} / \mathrm{TiO}_{2}$ to $529.6 \mathrm{eV}$. A slight decrease in oxygen lattice peak position due to plasma treatment has been previously observed [46].

(a)

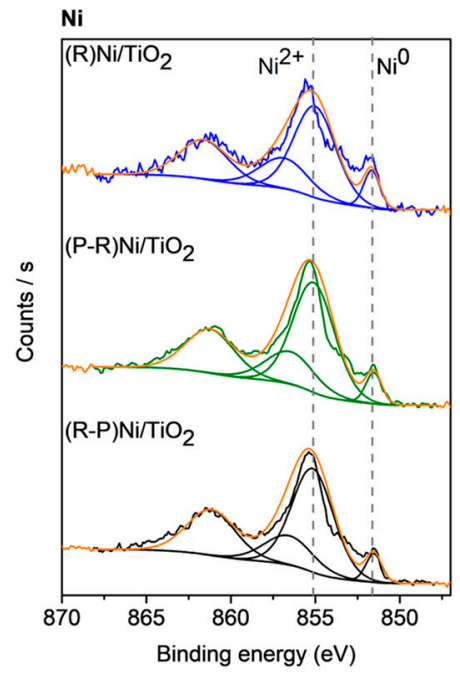

(b)

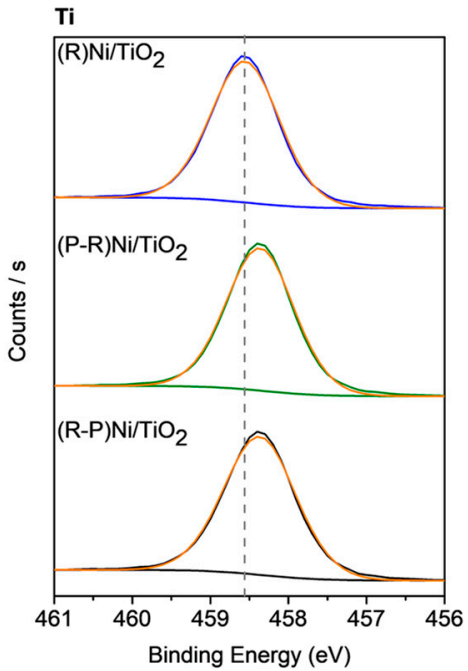

(c)

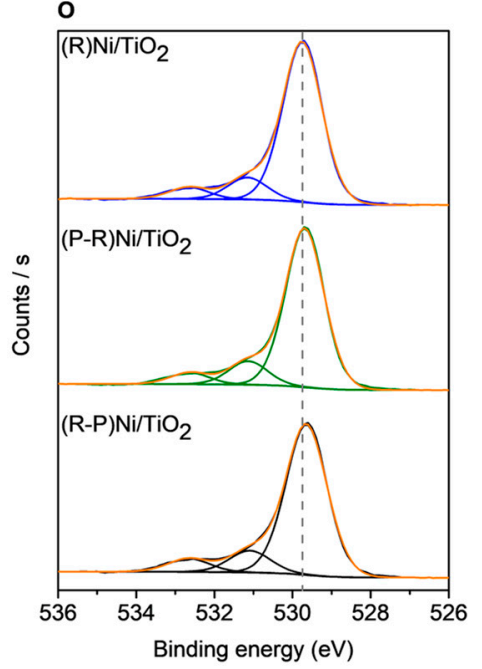

Figure 3. XPS spectra of pretreated $\mathrm{Ni} / \mathrm{TiO}_{2}:(\mathbf{a}) \mathrm{Ni} 2 \mathrm{p}_{3 / 2}$, (b) $\mathrm{Ti} 2 \mathrm{p}$, and (c) $\mathrm{O} 1 \mathrm{~s} . \mathrm{R}=$ reduced/passivated, $\mathrm{P}=$ plasma treated.

To further understand the interaction between $\mathrm{Ni}$ and the $\mathrm{TiO}_{2}$ support, TEM images were taken and EDS mapping was performed (Figure 4). The Ni deposits display little difference in size between the $(\mathrm{R}) \mathrm{Ni} / \mathrm{TiO}_{2}(17 \pm 5 \mathrm{~nm})$ and $(\mathrm{P}-\mathrm{R}) \mathrm{Ni} / \mathrm{TiO}_{2}(18 \pm 5 \mathrm{~nm})$ samples, consistent with the XRD crystallite sizes (Table 1). The (R-P)Ni/ $\mathrm{TiO}_{2}$ sample also exhibited Ni deposits of a similar size $(16 \pm 5 \mathrm{~nm})$. However, also present were additional finely dispersed $\mathrm{Ni}$ deposits. The sizes of the fine $\mathrm{Ni}$ deposits were not able to be accurately measured and, as such, were not included in the associated histogram (Figure 4). 


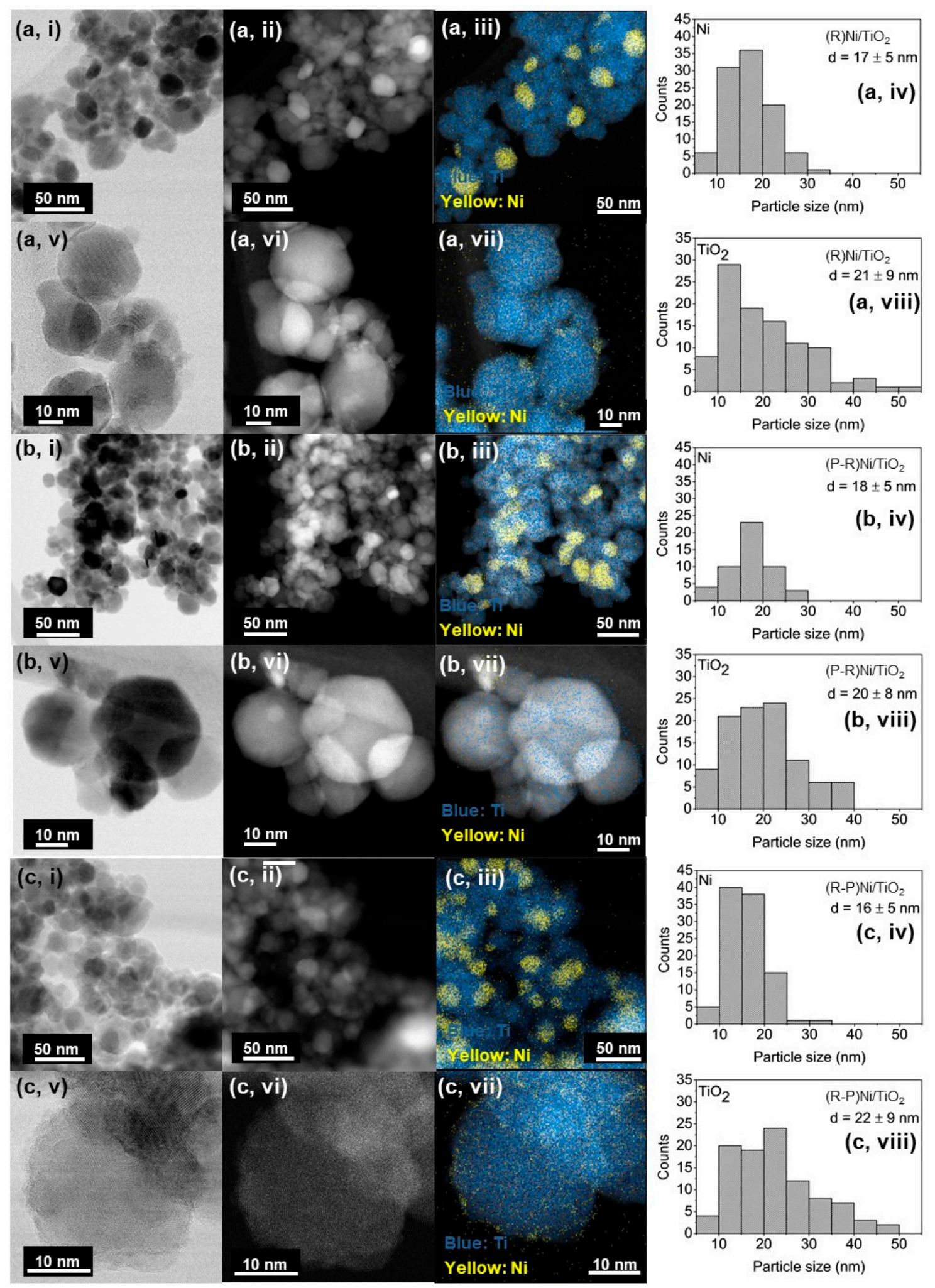

Figure 4. TEM images and EDS mapping of (a) (R)Ni/ $\mathrm{TiO}_{2}$, (b) (P-R)Ni/ $\mathrm{TiO}_{2}$ and (c) $(\mathrm{R}-\mathrm{P}) \mathrm{Ni} / \mathrm{TiO}_{2}$ including: (i,v) bright field images; (ii,vi) dark field images; (iii,vii) EDS mapping; and (iv,viii) particle size distribution histograms with range of particle counts $=50-100 . R=$ reduced $/$ passivated, $\mathrm{P}=$ plasma treated.

Characterisation of the catalyst properties indicates that plasma treatment modifies the $\mathrm{TiO}_{2}$. The modification is evident in changes to the surface texture of the $\mathrm{TiO}_{2}$ (Figure 4) and the shift in the Ti $2 p$ peak shift in the XPS spectra (Figure 3) for the plasma-treated samples. 
Plasma treatment also leads to an increase in $\mathrm{CO}_{2}$ adsorption by the neat $\mathrm{TiO}_{2}$ (Figure $2 \mathrm{~b}$ ) and structural modification as illustrated by the emergence of a new peak for $(\mathrm{P}) \mathrm{TiO}_{2}$ in the Raman spectra (Figure 1). Plasma treatment affected the Ni deposit properties, impacting the reducibility of (R-P)Ni/ $\mathrm{TiO}_{2}$ (Figure 1c,d). To understand the impact of the altered characteristics of the $\mathrm{Ni} / \mathrm{TiO}_{2}$ catalyst arising from the plasma treatment, the activity/selectivity of the catalysts for $\mathrm{CO}_{2}$ methanation under (i) photothermal (batchcirculated reactor system) and (ii) decoupled photo and thermal (continuous flow reactor system) conditions was evaluated.

\section{2. $\mathrm{CO}_{2}$ Methanation Results}

The effects of the pretreatment conditions on catalyst activity for the photothermal methanation reaction within the batch-circulated reactor system are shown in Figure 5a,b.
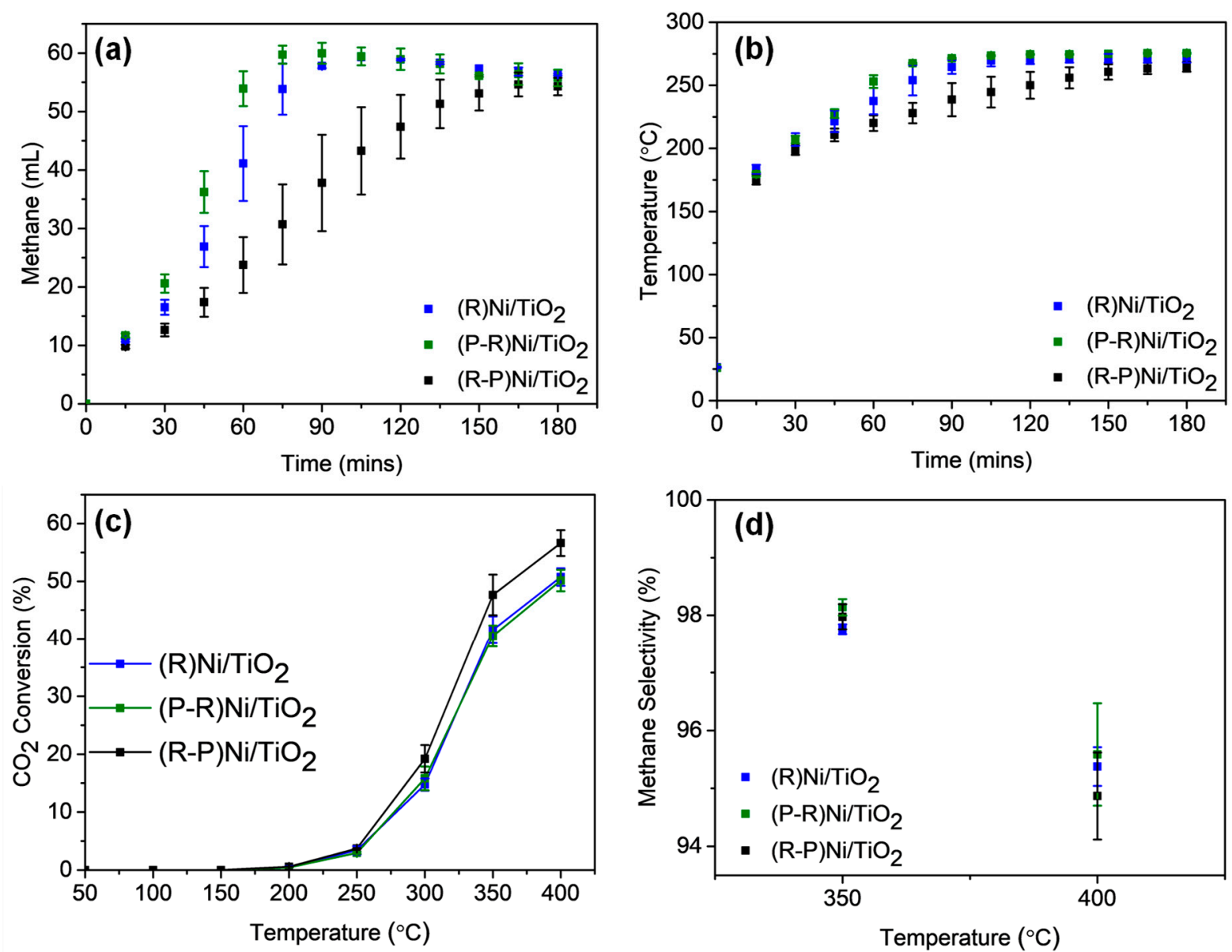

Figure 5. The influence of $\mathrm{Ni} / \mathrm{TiO}_{2}$ catalyst pretreatment on (a) methane formation and (b) the temperature profile during photothermal $\mathrm{CO}_{2}$ methanation in a batch-circulated reactor system. Catalyst loading $=100 \mathrm{mg}$; Initial reactant pressure = $\sim 15 \mathrm{kPa} \mathrm{CO} 2$ and $\sim 60 \mathrm{kPa} \mathrm{H}_{2}$; illumination provided by a $300 \mathrm{~W}$ Xenon lamp. The influence of $\mathrm{Ni} / \mathrm{TiO}_{2}$ catalyst pretreatment on (c) $\mathrm{CO}_{2}$ conversion and (d) methane selectivity during decoupled photo-and-thermal $\mathrm{CO}_{2}$ methanation in a continuous flow reactor system. Catalyst loading $=100 \mathrm{mg}$; reacting gas flow rate $=4 \mathrm{~mL} / \mathrm{min} \mathrm{CO}_{2}$ and $16 \mathrm{~mL} / \mathrm{min} \mathrm{H}_{2}$; illumination provided by a $300 \mathrm{~W}$ Xenon lamp. Thermal only reaction indicated by the filled markers $(\bullet) . \mathrm{R}=\mathrm{reduced} / \mathrm{passivated}$, $\mathrm{P}=$ plasma treated.

Within the batch-circulated reactor system, the methane formation trend followed the order: $(\mathrm{P}-\mathrm{R}) \mathrm{Ni} / \mathrm{TiO}_{2}>(\mathrm{R}) \mathrm{Ni} / \mathrm{TiO}_{2}>(\mathrm{R}-\mathrm{P}) \mathrm{Ni} / \mathrm{TiO}_{2}$ (Figure $\left.5 \mathrm{a}\right)$. (P-R)Ni/ $/ \mathrm{TiO}_{2}$ and (R)Ni/ $\mathrm{TiO}_{2}$ required $75 \mathrm{~min}$ and $90 \mathrm{~min}$, respectively, to achieve maximum $\mathrm{CH}_{4}$ formation with $\approx 100 \%$ selectivity (with trace $\mathrm{CO}$ ). A longer time period was required for methane formation to stabilise in the case of $(\mathrm{R}-\mathrm{P}) \mathrm{Ni} / \mathrm{TiO}_{2}$. The temperature profile for each of 
the $\mathrm{Ni} / \mathrm{TiO}_{2}$ samples is included in Figure $5 \mathrm{~b}$. The temperature for all catalysts reached $175-200{ }^{\circ} \mathrm{C}$ within the first $15 \mathrm{~min}$ due to the initial photothermal heating of the catalyst combined with the later exothermic heat from methane formation. Given the Ni in the pretreated $\mathrm{Ni} / \mathrm{TiO}_{2}$ catalysts was reducible below $250{ }^{\circ} \mathrm{C}$ (Figure $2 \mathrm{~d}$ ) following reduction and passivation of the catalysts, it is anticipated that catalysts are converted to their reduced form during the batch reaction. Absorbance by the $\mathrm{Ni} / \mathrm{TiO}_{2}$ catalysts in the infrared region contributed to the localised heating [47]. Consequently, the capacity of the catalysts for full spectrum absorbance was beneficial for the reaction. With increasing methane production, the temperature further increased and reached $250-280{ }^{\circ} \mathrm{C}$ after $3 \mathrm{~h}$. The further temperature increase arising from the exothermic nature of methanation can promote better catalyst reduction and contribute to greater methane production [16]. Both $(\mathrm{P}-\mathrm{R}) \mathrm{Ni} / \mathrm{TiO}_{2}$ and $(\mathrm{R}) \mathrm{Ni} / \mathrm{TiO}_{2}$ exhibit a similar temperature profile while the temperature profile for (R-P)Ni $/ \mathrm{TiO}_{2}$ was generally lower. It is apparent that the temperature profile can be correlated to methane formation with $(\mathrm{P}-\mathrm{R}) \mathrm{Ni} / \mathrm{TiO}_{2}$ achieving the highest temperature, followed by (R)Ni/ $\mathrm{TiO}_{2}$ and $(\mathrm{R}-\mathrm{P}) \mathrm{Ni} / \mathrm{TiO}_{2}$.

The influences of light and heat were decoupled in the continuous flow reactor system, where a furnace (separate from the light source) was used to heat the catalyst bed. $\mathrm{CO}_{2}$ conversion and methane selectivity for thermal-only input are shown in Figure 5c,d. $\mathrm{CO}_{2}$ conversion under thermal-only conditions was observable from $200{ }^{\circ} \mathrm{C}$ onwards, which is consistent with the findings from the batch photothermal catalytic reactor. A significant increase in $\mathrm{CO}_{2}$ conversion was observed with increasing temperature for all catalysts, particularly from $300{ }^{\circ} \mathrm{C}$ to $350{ }^{\circ} \mathrm{C}$, with methane as the sole product up to $350{ }^{\circ} \mathrm{C}$. A significant difference in $\mathrm{CO}_{2}$ conversion is not apparent over the temperature range 250$400{ }^{\circ} \mathrm{C}$ for any of the catalysts. Despite the different pretreatments inducing variations to the catalyst properties, such as reducibility and defect density, the $\mathrm{CO}_{2}$ conversion and methane selectivity were not altered. The indifference indicates that the catalyst modification was only effective under photothermal conditions.

Adding illumination to the thermal stimulus can provide better understanding on the influence of light on the reaction, particularly across the UV-visible region. The addition of light, Figure S5, to the thermal conditions did not lead to any significant increase in $\mathrm{CO}_{2}$ conversion or change to product selectivity. Subsequently, photothermal $\mathrm{CO}_{2}$ conversion by the $\mathrm{Ni} / \mathrm{TiO}_{2}$ catalysts appears to be thermally dominant. Under both conditions-thermal-only and light-plus-thermal conditions-methane selectivity decreased from $350{ }^{\circ} \mathrm{C}$ onwards in favour of $\mathrm{CO}$ formation due to the reverse-water gas shift reaction [11].

The thermal dominance during photothermal $\mathrm{CO}_{2}$ conversion indicates that the absorbance of light from the NIR portion of the spectrum is crucial for reaction feasibility. While catalyst modifications induced by pretreatment, such as greater $\mathrm{CO}_{2}$ adsorption, $\mathrm{TiO}_{2}$ defects, and a change in metal-support interaction, did not promote greater $\mathrm{CO}_{2}$ conversion under the decoupled photo-and-thermal condition (continuous flow reactor), they do significantly influence the photothermal catalytic activity (cyclic batch reactor). Importantly, the order in which the plasma and reduction/passivation treatments were applied influenced the catalytic activity of the $\mathrm{Ni} / \mathrm{TiO}_{2}$.

Others have examined defects generated in $\mathrm{TiO}_{2}$ as a consequence of plasma treatment. Bharti et al. reported that plasma treatment in an air environment could induce $\mathrm{Ti}^{3+}$ and oxygen vacancies in a $\mathrm{TiO}_{2}$ thin film [46]. The higher activity of $(\mathrm{P}-\mathrm{R}) \mathrm{Ni} / \mathrm{TiO}_{2}$ compared to $(\mathrm{R}-\mathrm{P}) \mathrm{Ni} / \mathrm{TiO}_{2}$ in our work can be related to additional defects formed and their ensuing stability arising from the different pretreatment sequences. Chen et al. found that plasma treating $\mathrm{Pt} / \mathrm{CeO}_{2}$ followed by $20 \% \mathrm{H}_{2} / \mathrm{N}_{2}$ thermal treatment led to higher toluene catalytic oxidation, compared to thermal then plasma treatment. The plasma treatment affected the surface oxygen defects and Pt-Ce interaction. When thermally treating the catalyst after plasma treatment, more defects could be generated via greater hydrogen dissociation on the plasma-generated defect sites [48]. In our case, while the impact of plasma treatment was most prominent for $(\mathrm{R}-\mathrm{P}) \mathrm{Ni} / \mathrm{TiO}_{2}$, the changes were not necessarily beneficial for enhancing photothermal $\mathrm{CO}_{2}$ hydrogenation relative to $(\mathrm{R}) \mathrm{Ni} / \mathrm{TiO}_{2}$. The thermal treatment 
can stabilise the catalyst structure and subsequently minimise the impact of any ensuing plasma treatment [24]. Consequently, the results suggest that the most effectual approach for the $\mathrm{Ni} / \mathrm{TiO}_{2}$ catalyst is to thermally treat the defected catalyst to stabilise the defects generated from the plasma treatment.

\section{Conclusions}

The influence of $\mathrm{Ni} / \mathrm{TiO}_{2}$ catalyst pretreatment strategy on the generation and stabilisation of surface defects active for the photothermal $\mathrm{CO}_{2}$ methanation reaction was examined. The sequence of two pretreatment steps, involving a He-plasma stage and a reduction/passivation stage, were switched, with the ensuing impact on defect generation and, in turn, catalyst activity, assessed. The catalyst comprised a $\mathrm{TiO}_{2}$ support prepared via FSP which was loaded with a $\mathrm{Ni}$ catalyst. When the as-prepared $\mathrm{NiO} / \mathrm{TiO}_{2}$ was treated with plasma, the subsequent reduction/passivation step stabilised the plasma-generated defects on the $\mathrm{TiO}_{2}$ support, as evident from XPS, and Raman analysis. This increase in defects resulted in an increased $\mathrm{CO}_{2}$ interaction (shown in the $\mathrm{CO}_{2}$-TPD of the plasma-treated $\mathrm{TiO}_{2}$ ). Ultimately, these increased surface $\mathrm{TiO}_{2}$ defects resulted in higher photothermal catalytic performance. When reduction/passivation was performed prior to plasma treatment, the reduction/passivation imbued the $\mathrm{NiO} / \mathrm{TiO}_{2}$ with a greater resistance to subsequent defecting by the plasma treatment. It was evident, through $\mathrm{H}_{2}-\mathrm{TPR}$ of the $\mathrm{Ni} / \mathrm{TiO}_{2}$ samples (after reduction and passivation), that a change in metal-support interaction occurred as a result of plasma treatment after reduction. Deconvolution of the light and heat effects demonstrated that the photothermal catalytic reaction was thermally dominant with the light as a heat source. The work highlights the importance of the material pretreatment strategy when using plasma as a means to generate active defect sites within a catalyst. If not performed correctly, the potential benefits of plasma treatment can be lost.

Supplementary Materials: The following are available online at https: / www.mdpi.com/article / 10.3390/ma14154195/s1, Figure S1: $\mathrm{N}_{2}$ adsorption/desorption isotherm and pore size distribution of $(\mathrm{a}, \mathrm{d}) \mathrm{TiO}_{2}$, (b,e) $\mathrm{NiO} / \mathrm{TiO}_{2}$, and $(\mathrm{c}, \mathrm{f})(\mathrm{P}) \mathrm{NiO} / \mathrm{TiO}_{2}$, respectively, Figure S2: XRD patterns of (a) $\mathrm{TiO}_{2}$ and $\mathrm{NiO} / \mathrm{TiO}_{2}$ and (b) $\mathrm{Ni} / \mathrm{TiO}_{2}$ catalysts following different pretreatment approaches. $\mathrm{R}=$ reduced/passivated, $\mathrm{P}=$ plasma treated. JCPDS: 00-044-1159 (NiO), 00-004-0850 (Ni), 00-0211272 (anatase $\mathrm{TiO}_{2}$ ), and 98-005-3997 (rutile $\mathrm{TiO}_{2}$ ), Figure S3: (a) EPR and (b) Raman spectra of as-prepared $\mathrm{TiO}_{2}$ following different pretreatment approaches. $\mathrm{R}=$ reduced/passivated, $\mathrm{P}=$ plasma treated, Figure S4: The influence of $\mathrm{Ni} / \mathrm{TiO}_{2}$ catalyst pretreatment on (a) $\mathrm{CO}_{2}$ conversion and (b) methane selectivity during decoupled photo and-thermal $\mathrm{CO}_{2}$ methanation in a continuous flow reactor system. Catalyst loading $=100 \mathrm{mg}$; Reacting gas flow rate $=4 \mathrm{~mL} / \mathrm{min} \mathrm{CO}_{2}$ and $16 \mathrm{~mL} / \mathrm{min}$ $\mathrm{H}_{2}$; illumination provided by a $300 \mathrm{~W}$ Xenon lamp. Thermal only reaction indicated by the filled markers $(\bullet)$. Photo-and-thermal reaction indicated by the open markers $(\bigcirc)$. R $=$ reduced/passivated, $\mathrm{P}=$ plasma treated.

Author Contributions: Conceptualization, S.J., E.C.L., R.A. and J.S.; formal analysis, S.J., S.L., E.C.L., T.H.T. and B.X.; investigation, S.J., S.L., J.H., E.C.L. and B.X.; supervision, E.C.L., T.H.T., R.A. and J.S.; writing—original draft, S.J.; writing—review—editing, J.H., E.C.L., T.H.T., R.A. and J.S. All authors have read and agreed to the published version of the manuscript.

Funding: The work was supported by the Australian Research Council under the Laureate Fellowship Scheme-FL140100081 and is gratefully acknowledged.

Institutional Review Board Statement: Not applicable.

Informed Consent Statement: Not applicable.

Data Availability Statement: The data presented in this study are available in this article and the Supplementary Information.

Acknowledgments: Characterisation conducted at the UNSW Mark Wainwright Analytical Centre and the University of Wollongong Electron Microscopy Centre (David Mitchell) was invaluable to the research. We would also like to thank Constantine Tsounis for his assistance with TEM and EDS at UNSW. 
Conflicts of Interest: The authors declare no conflict of interest. The funders had no role in the design of the study; in the collection, analyses, or interpretation of data; in the writing of the manuscript, or in the decision to publish the results.

\section{References}

1. Liu, Q.; Wu, L.; Jackstell, R.; Beller, M. Using carbon dioxide as a building block in organic synthesis. Nat. Commun. 2015, 6. [CrossRef]

2. Cuéllar-Franca, R.M.; Azapagic, A. Carbon capture, storage and utilisation technologies: A critical analysis and comparison of their life cycle environmental impacts. J. CO2 Util. 2015, 9, 82-102. [CrossRef]

3. Ghaib, K.; Nitz, K.; Ben-Fares, F.-Z. Chemical Methanation of $\mathrm{CO}_{2}$ : A Review. ChemBioEng Rev. 2016, 3, 266-275. [CrossRef]

4. Mac Kinnon, M.A.; Brouwer, J.; Samuelsen, S. The role of natural gas and its infrastructure in mitigating greenhouse gas emissions, improving regional air quality, and renewable resource integration. Prog. Energy Combust. Sci. 2018, 64, 62-92. [CrossRef]

5. Jia, J.; Wang, H.; Lu, Z.; O’Brien, P.G.; Ghoussoub, M.; Duchesne, P.; Zheng, Z.; Li, P.; Qiao, Q.; Wang, L.; et al. Photothermal Catalyst Engineering: Hydrogenation of Gaseous $\mathrm{CO}_{2}$ with High Activity and Tailored Selectivity. Adv. Sci. 2017, 4. [CrossRef]

6. Meng, X.; Wang, T.; Liu, L.; Ouyang, S.; Li, P.; Hu, H.; Kako, T.; Iwai, H.; Tanaka, A.; Ye, J. Photothermal conversion of CO ${ }_{2}$ into $\mathrm{CH}_{4}$ with $\mathrm{H}_{2}$ over Group VIII Nanocatalysts: An alternative approach for solar fuel production. Angew. Chem. Int. Ed. 2014, 4, 11662-11666. [CrossRef]

7. Ren, J.; Ouyang, S.; Xu, H.; Meng, X.; Wang, T.; Wang, D.; Ye, J. Targeting Activation of $\mathrm{CO}_{2}$ and $\mathrm{H}_{2}$ over Ru-Loaded Ultrathin Layered Double Hydroxides to Achieve Efficient Photothermal $\mathrm{CO}_{2}$ Methanation in Flow-Type System. Adv. Energy Mater. 2016, 1601657. [CrossRef]

8. Le, T.A.; Kang, J.K.; Park, E.D. $\mathrm{CO}$ and $\mathrm{CO}_{2}$ Methanation Over Ni/SiC and $\mathrm{Ni} / \mathrm{SiO}_{2}$ Catalysts. Top. Catal. 2018, 61, 1537-1544. [CrossRef]

9. Zhou, R.; Rui, N.; Fan, Z.; Liu, C. Effect of the structure of $\mathrm{Ni} / \mathrm{TiO}_{2}$ catalyst on $\mathrm{CO}_{2}$ methanation. Int. J. Hydrog. Energy 2016, 41, 22017-22025. [CrossRef]

10. Wierzbicki, D.; Baran, R.; Dębek, R.; Motak, M.; Grzybek, T.; Gálvez, M.E.; Da Costa, P. The influence of nickel content on the performance of hydrotalcite-derived catalysts in $\mathrm{CO}_{2}$ methanation reaction. Int. J. Hydrog. Energy 2017, 42, 23548-23555. [CrossRef]

11. Kesavan, J.K.; Luisetto, I.; Tuti, S.; Meneghini, C.; Iucci, G.; Battocchio, C.; Mobilio, S.; Casciardi, S.; Sisto, R. Nickel supported on YSZ: The effect of Ni particle size on the catalytic activity for $\mathrm{CO}_{2}$ methanation. J. CO2 Util. 2018, 23, 200-211. [CrossRef]

12. Kim, A.; Sanchez, C.; Patriarche, G.; Ersen, O.; Moldovan, S.; Wisnet, A.; Sassoye, C.; Debecker, D.P. Selective $\mathrm{CO}_{2}$ methanation on $\mathrm{Ru} / \mathrm{TiO}_{2}$ catalysts: Unravelling the decisive role of the $\mathrm{TiO}_{2}$ support crystal structure. Catal. Sci. Technol. 2016, 6, 8117-8128. [CrossRef]

13. Qin, Z.; Wang, X.; Dong, L.; Su, T.; Li, B.; Zhou, Y.; Jiang, Y.; Luo, X.; Ji, H. $\mathrm{CO}_{2}$ methanation on Co/TiO 2 catalyst: Effects of Y on the support. Chem. Eng. Sci. 2019, 210, 115245. [CrossRef]

14. Low, J.; Cheng, B.; Yu, J. Surface modification and enhanced photocatalytic $\mathrm{CO}_{2}$ reduction performance of TiO ${ }_{2}$ : A review. Appl. Surf. Sci. 2017, 392, 658-686. [CrossRef]

15. Xu, M.; Hu, X.; Wang, S.; Yu, J.; Zhu, D.; Wang, J. Photothermal effect promoting $\mathrm{CO}_{2}$ conversion over composite photocatalyst with high graphene content. J. Catal. 2019, 377, 652-661. [CrossRef]

16. Jantarang, S.; Lovell, E.C.; Tan, T.H.; Scott, J.; Amal, R. Role of support in photothermal carbon dioxide hydrogenation catalysed by Ni/CexTiyO ${ }_{2}$. Prog. Nat. Sci. Mater. Int. 2018, 28, 168-177. [CrossRef]

17. Li, Z.; Liu, J.; Shi, R.; Waterhouse, G.I.N.; Wen, X.D.; Zhang, T. Fe-Based Catalysts for the Direct Photohydrogenation of $\mathrm{CO}_{2}$ to Value-Added Hydrocarbons. Adv. Energy Mater. 2021, 11, 2002783. [CrossRef]

18. Batzill, M.; Morales, E.H.; Diebold, U. Influence of nitrogen doping on the defect formation and surface properties of $\mathrm{TiO}_{2} \mathrm{rutile}$ and anatase. Phys. Rev. Lett. 2006, 96. [CrossRef]

19. Pecchi, G.; Jiliberto, M.G.; Buljan, A.; Delgado, E.J. Relation between defects and catalytic activity of calcium doped LaFeO 3 perovskite. Solid State Ion. 2011, 187, 27-32. [CrossRef]

20. Li, Z.H.; Tian, S.X.; Wang, H.T.; Tian, H.B. Plasma treatment of Ni catalyst via a corona discharge. J. Mol. Catal. A Chem. 2004, 211, 149-153. [CrossRef]

21. Liu, C.J.; Yu, K.; Zhang, Y.P.; Zhu, X.; He, F.; Eliasson, B. Characterization of plasma treated Pd/HZSM-5 catalyst for methane combustion. Appl. Catal. B Environ. 2004, 47, 95-100. [CrossRef]

22. Liu, F.; Leung, Y.H.; Djurišić, A.B.; Ng, A.M.C.; Chan, W.K.; Ng, K.L.; Wong, K.S.; Liao, C.; Shih, K.; Surya, C. Effect of plasma treatment on native defects and photocatalytic activities of zinc oxide tetrapods. J. Phys. Chem. C 2014, 118, 22760-22767. [CrossRef]

23. Quaas, M.; Wulff, H.; Ivanova, O.; Helm, C.A. Plasma chemical reactions of thin nickel films. Surf. Interface Anal. 2008, 40, 552-555. [CrossRef]

24. Horlyck, J.; Nashira, A.; Lovell, E.; Daiyan, R.; Bedford, N.; Wei, Y.; Amal, R.; Scott, J. Plasma Treating Mixed Metal Oxides to Improve Oxidative Performance via Defect Generation. Materials 2019, 12, 2756. [CrossRef] 
25. Pastor-Pérez, L.; Belda-Alcázar, V.; Marini, C.; Pastor-Blas, M.M.; Sepúlveda-Escribano, A.; Ramos-Fernandez, E.V. Effect of cold Ar plasma treatment on the catalytic performance of $\mathrm{Pt} / \mathrm{CeO}_{2}$ in water-gas shift reaction (WGS). Appl. Catal. B Environ. 2018, 225, 121-127. [CrossRef]

26. Saputera, W.H.; Tahini, H.A.; Sabsabi, M.; Tan, T.H.; Bedford, N.M.; Lovell, E.; Cui, Y.; Hart, J.N.; Friedmann, D.; Smith, S.C.; et al. Light-Induced Synergistic Multidefect Sites on $\mathrm{TiO}_{2} / \mathrm{SiO}_{2}$ Composites for Catalytic Dehydrogenation. ACS Catal. 2019, 9, 2674-2684. [CrossRef]

27. Tan, T.H.; Scott, J.; Ng, Y.H.; Taylor, R.A.; Aguey-Zinsou, K.F.; Amal, R. Understanding Plasmon and Band Gap Photoexcitation Effects on the Thermal-Catalytic Oxidation of Ethanol by $\mathrm{TiO}_{2}$-Supported Gold. ACS Catal. 2016, 6, 1870-1879. [CrossRef]

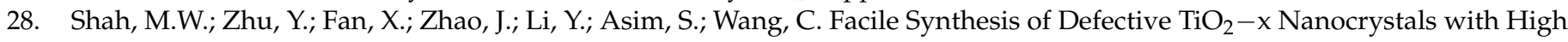
Surface Area and Tailoring Bandgap for Visible-light Photocatalysis. Sci. Rep. 2015, 5. [CrossRef]

29. Duan, Y.; Zhang, M.; Wang, L.; Wang, F.; Yang, L.; Li, X.; Wang, C. Plasmonic Ag-TiO $2-x$ nanocomposites for the photocatalytic removal of NO under visible light with high selectivity: The role of oxygen vacancies. Appl. Catal. B Environ. 2017. [CrossRef]

30. Kalaiarasi, S.; Sivakumar, A.; Martin Britto Dhas, S.A.; Jose, M. Shock wave induced anatase to rutile $\mathrm{TiO}_{2}$ phase transition using pressure driven shock tube. Mater. Lett. 2018, 219, 72-75. [CrossRef]

31. Tian, F.; Zhang, Y.; Zhang, J.; Pan, C. Raman spectroscopy: A new approach to measure the percentage of anatase $\mathrm{TiO}_{2}$ exposed (001) facets. J. Phys. Chem. C 2012, 116, 7515-7519. [CrossRef]

32. Surmacki, J.; Wroński, P.; Szadkowska-Nicze, M.; Abramczyk, H. Raman spectroscopy of visible-light photocatalyst-Nitrogendoped titanium dioxide generated by irradiation with electron beam. Chem. Phys. Lett. 2013, 566, 54-59. [CrossRef]

33. Yu, J.; Xiang, Q.; Zhou, M. Preparation, characterization and visible-light-driven photocatalytic activity of Fe-doped titania nanorods and first-principles study for electronic structures. Appl. Catal. B Environ. 2009, 90, 595-602. [CrossRef]

34. Yin, W.J.; Chen, S.; Yang, J.H.; Gong, X.G.; Yan, Y.; Wei, S.H. Effective band gap narrowing of anatase $\mathrm{TiO}_{2}$ by strain along a soft crystal direction. Appl. Phys. Lett. 2010, 96. [CrossRef]

35. Mateo, D.; Morlanes, N.; Maity, P.; Shterk, G.; Mohammed, O.F.; Gascon, J. Efficient Visible-Light Driven Photothermal Conversion of $\mathrm{CO}_{2}$ to Methane by Nickel Nanoparticles Supported on Barium Titanate. Adv. Funct. Mater. 2021, 31. [CrossRef]

36. Chen, J.; Albella, P.; Pirzadeh, Z.; Alonso-González, P.; Huth, F.; Bonetti, S.; Bonanni, V.; Åkerman, J.; Nogués, J.; Vavassori, P.; et al. Plasmonic nickel nanoantennas. Small 2011, 7, 2341-2347. [CrossRef]

37. Nguyen Thanh, D.; Kikhtyanin, O.; Ramos, R.; Kothari, M.; Ulbrich, P.; Munshi, T.; Kubička, D. Nanosized TiO 2 -A promising catalyst for the aldol condensation of furfural with acetone in biomass upgrading. Catal. Today 2016, 277, 97-107. [CrossRef]

38. Liu, L.; Zhao, H.; Andino, J.M.; Li, Y. Photocatalytic $\mathrm{CO}_{2}$ reduction with $\mathrm{H}_{2} \mathrm{O}$ on $\mathrm{TiO}_{2}$ nanocrystals: Comparison of anatase, rutile, and brookite polymorphs and exploration of surface chemistry. ACS Catal. 2012, 2, 1817-1828. [CrossRef]

39. Inturi, S.N.R.; Suidan, M.; Smirniotis, P.G. Influence of synthesis method on leaching of the $\mathrm{Cr}^{-T i O}{ }_{2}$ catalyst for visible light liquid phase photocatalysis and their stability. Appl. Catal. B Environ. 2016, 180, 351-361. [CrossRef]

40. Meeyoo, V.; Panchan, N.; Phongprueksathat, N.; Traitangwong, A.; Guo, X.; Li, C.; Rirksomboon, T. Low Temperature Methanation of $\mathrm{CO}_{2}$ on High Ni Content Ni-Ce-ZrOs Catalysts Prepared via One-Pot Hydrothermal Synthesis. Catalysts 2019, 10, 32. [CrossRef]

41. Shen, Y.; Lua, A.C. Sol-gel synthesis of Ni and Ni supported catalysts for hydrogen production by methane decomposition. RSC Adv. 2014, 4, 42159-42167. [CrossRef]

42. Grosvenor, A.P.; Biesinger, M.C.; Smart, R.C., St.; McIntyre, N.S. New interpretations of XPS spectra of nickel metal and oxides. Surf. Sci. 2006, 600, 1771-1779. [CrossRef]

43. An, H.R.; Park, S.Y.; Kim, H.; Lee, C.Y.; Choi, S.; Lee, S.C.; Seo, S.; Park, E.C.; Oh, Y.K.; Song, C.G.; et al. Advanced nanoporous $\mathrm{TiO}_{2}$ photocatalysts by hydrogen plasma for efficient solar-light photocatalytic application. Sci. Rep. 2016, 6. [CrossRef] [PubMed]

44. Rodríguez, J.L.; Poznyak, T.; Valenzuela, M.A.; Tiznado, H.; Chairez, I. Surface interactions and mechanistic studies of 2,4dichlorophenoxyacetic acid degradation by catalytic ozonation in presence of $\mathrm{Ni} / \mathrm{TiO}_{2}$. Chem. Eng. J. 2013, 222, 426-434. [CrossRef]

45. Tahir, M.; Tahir, B.; Amin, N.A.S.; Muhammad, A. Photocatalytic $\mathrm{CO}_{2}$ methanation over $\mathrm{NiO} / \mathrm{In}_{2} \mathrm{O}_{3}$ promoted TiO${ }_{2}$ nanocatalysts using $\mathrm{H}_{2} \mathrm{O}$ and/or $\mathrm{H}_{2}$ reductants. Energy Convers. Manag. 2016, 119, 368-378. [CrossRef]

46. Bharti, B.; Kumar, S.; Lee, H.N.; Kumar, R. Formation of oxygen vacancies and Ti3+ state in $\mathrm{TiO}_{2}$ thin film and enhanced optical properties by air plasma treatment. Sci. Rep. 2016, 6. [CrossRef]

47. Li, J.; Ye, Y.; Ye, L.; Su, F.; Ma, Z.; Huang, J.; Xie, H.; Dorokin, D.E.; Zimina, A.; Grunwaldt, J.-D.; et al. Sunlight induced photo-thermal synergistic catalytic $\mathrm{CO}_{2}$ conversion via localized surface plasmon resonance of MoO3-x. J. Mater. Chem. A 2019, 7, 2821-2830. [CrossRef]

48. Chen, B.; Wang, B.; Sun, Y.; Wang, X.; Fu, M.; Wu, J.; Chen, L.; Tan, Y.; Ye, D. Plasma-Assisted Surface Interactions of Pt/CeO 2 Catalyst for Enhanced Toluene Catalytic Oxidation Bingxu. Catalysts 2019, 9, 2. [CrossRef] 